\title{
The Effect of Disney Movie in Creating Children Stereotype as Reflected in the Little Mermaid (1989) Movie
}

\author{
Uswatun Hasanah*, Cindy Kurnia Octaviyanti \\ English Literature in College of Languages, Sultan Agung Islamic University (UNISSULA), Semarang, Indonesia
}

\begin{abstract}
How to cite this paper: Hasanah, U., \& Octaviyanti, C. K. (2018). The Effect of Disney Movie in Creating Children Stereotype as Reflected in the Little Mermaid (1989) Movie. The Educational Review, USA, 2(3), 233-237.

http://dx.doi.org/10.26855/er.2018.03.005
\end{abstract}

*Corresponding author: Uswatun Hasanah, S.S, English Literature in College of Languages, Sultan Agung Islamic University (UNISSULA), Semarang, Indonesia.

\begin{abstract}
One of the ways for children learning things is by literary work. Parents usually improve the children knowledge about life by literary work. Most parents choose the entertaining one such as cartoon movie. One of the most children's favorite cartoon movie is The Little Mermaid (1989) by Walt Disney. It tells the life of a mermaid who wants to be normal human. Unfortunately, the thing that people should realize is that not all Disney movies bring more good than harm. This paper is going to analyze two effects deal with children stereotype. First about beauty stereotype and second the ideas of life stereotype. The aim of this research is that showing the stereotype effects' appear in The Little Mermaid. In conclusion not all things describe in The Little Mermaid are suitable for children's real life. The Little Mermaid has become the representative of most Disney movie by the story. It is harm for children because it influences the process of children's character building.
\end{abstract}

Keywords

Children's Stereotype, Cartoon Movie, Building Character

\section{Introduction}

Education can be started as early as possible. Not only education in terms of academic but also for character building as well. Psychologist most says that children are the best phase of human in learning something. In some researches show that children in $4-12$ years old are in the phase named golden age. In this phase, children are easier to memorize everything well. Children tend to imitate everything they see.

Most of children spend their time for fun activity such as playing and watching. Even though in the range of 4-12 years old children have already study at school but what they do at school also will not far from playing and watching. Teachers often deliver the material through games or watching movies so the learning process will be as fun as possible. In conclusion, when they start watching they start learning.

The most selected movie genre was chosen by parents or teacher is cartoon movie. Parent expects that cartoon movie is not only as an amusement for children but also as a media for them to learn something such as the moral value that can be taken. The most famous cartoon movie in children is produced by Walt Disney. Starting the career with "Micky Mouse", Disney becomes big company who produced hundreds even more cartoon movie. In 1995, Disney movie took part as the biggest market share. 
Disney produces cartoon movie with an interesting visualization appears in the movie. The visualization is one of the factors of the Disney's popularity. In the other side, they create various characters and stories. The story often tells about the life of society and kingdom. It mixes with the love story between prince and princess and has a happy ending.

The Little Mermaid produced in 1989 is one of Disney cartoon movies. It tells the life of a mermaid who wants to be normal human. Even though this movie produced in years ago, but this movie still become children's favorite movie and almost all children acknowledge this movie. In the other hand, not all Disney movies bring more good than harm. People should realize that it is possible for children to adopt the wrong things from the movie.

That kind of possibility also appears in The Little Mermaid. This paper uses descriptive qualitative approach which tries to analyze how The Little Mermaid influences children in creating life's stereotype and explains the effect of the movie for children. The Little Mermaid becomes the primary data in this paper because The Little Mermaid could be one of the representative of all Disney movies in terms of plot, characteristic and effect towards children because the similarity of plot and characters between The Little Mermaid and some others Disney movies. Moreover as the movie has been produced in more than 2 decades ago but this movie still becomes children's favorite movie of all the time.

\section{Analysis}

Children and cartoon are two things that could not be separated. In Indonesia, cartoon becomes a program which air in student's break time or even in the preparation of them going to school. Cartoon usually airs in the morning everyday or in the evening. "Children begin watching cartoons on television at an early age of six months and by the age two or three children become enthusiastic viewers. The children are at discretion to choose the cartoon programs which in turn indirectly influences their development." (Sudha, 2011). Based on the quotation above it is clearly explained that cartoons indirectly influence children development and in fact children start watching cartoons in the early of their age.

Development means here is not only about physical development but also mental development. Sudha continues that "Children learn and develop skills by interacting, observing and experiencing the world around them. The environment associated with the child influences the child behaviour." (Sudha, 2011). By logic, if what the children do routinely is watching cartoon movie, it is surely influencing the childlen behaviour development because basically children learn by observing and experiencing the world around them.

A research has been done in Gunung Terang, Bandar Lampung in 57 children in the range of 6-12 years old regarding to the effect of watching cartoon movies. It shows that most of them is often watching cartoon movies and imitate what they see in the movie, such as imitate the conversation among characters, imitate the behaviour of the character. Includes the bad behaviour such as any violence done by the character and mocking utterance.

Above research shows that first, it is possible for cartoon shows bad things and second, Children tend to imitate everything they see since naturally they still cannot separate the good and bad attitude. Above effects are effects that the writers want to show after children watching The Little Mermaid. It is influencing the children in building up their character in term of stereotype after watching the movie.

The plot inside The Little Mermaid stimulates children to create the stereotype in their mind after watching it. There are two classifications of stereotype here, first the beauty stereotype and second ideas of life stereotype. The Little Mermaid influences children to define the word "beauty" and the word "happily ever after". In The Little Mermaid Princess Ariel as the main character depicts the stereotype of beauty in woman and her ideas of life.

The idea of stereotype explained by Lippmann in his writing. Lippmann (1922) introduced the term 'stereotype' to refer to the typical picture that comes to mind when thinking about a particular social group. According to Lippmann, stereotype as the result of watching The Little Mermaid is how children having the typical picture in their mind after watching 
The Little Mermaid. After that, the typical picture will automatically applied in everyday life. Unfortunately, what appears in the movie is different with the everyday life, and make a wrong judgement in social life.

Stereotypes imply a substantial amount of information about people beyond their immediately apparent surface qualities and generate expectations about group members' anticipated behavior in new situations. In general, stereotypes produce a readiness to perceive behaviors or characteristics that are consistent with the stereotype. (Oakes\&Turner, 1990)

Based on Oakes and Turner, stereotype related with the input of information. They explain how stereotype influence life, because it is creating the appearance of group members of social group and their behaviour.

When children watch The Little Mermaid they will perceive behaviors or characteristic from the movie and simply imitate it because children are immature irrationally and emotionally in considering good and bad. The Liitle Mermaid has Princess Aurel as the main and protagonist character. She is depicted as the seventh daughter who is the most beautiful daughter of her dad, Triton, the king of sea. Why she remarks by all as the most beautiful one because she has beautiful voice, tall and slim body, long hair, and cheerful personality. With her kind heart she saves Eric, the man who drowns. "You'll have your looks! Your pretty face! And don't underestimate the importance of body language! Ha!" (00:41:10,780 --> 00:41:20,300). From the quotation said by Ursula, as a person around her it depicts how beauty defines by Princess Ariel's physical appearance. This type of girl, not only appears in Little Mermaid, but always seen in every Disney movie. It makes children create the beauty stereotype if they have the same character like all princesses in Disney.

Not only the beautiful face and perfect body all Disney girl often have beautiful voice so they are good at singing. It is also seen in The Little Mermaid. Princess Ariel has beautiful voice, and makes Ursula jealous of it. Her beautiful voice was also the reason why Eric falls in love with her in the first sight. "A girl-rescued me... She was-singing...she had the most - beautiful voice." (00:24:48,620 --> 00:24:58,780). The quotation above shows how a girl looks interesting in front of man by the voice she has. Almost in all Disney movies the girl main character will consider as beautiful one if fulfilled above condition. In addition, they who are beautiful become the good person while they who have uninteresting physical appearance consider as the bad one.

In the other hand, the bad and cruel character is shown by Ursula. Ursula is depicted as witch person who wants to have the beautiful voice of Princess Aurel. She is fat and has a bad face, with the witch personality. She does everything to get Princess Aurel's voice and make everyone inside the sea amazed of her. "Make your choice! I'm a very busy woman. And I haven't got all day. It won't cost much. Just your voice!” (00:41:49,660 --> 00:41:55,420). The quotation is the lyrics of a song by Ursula. Ursula who doesn't have the beautiful voice like Princess Ariel, she uses her magic power to change Princess Ariel becomes human with Ariel's voice as the return.

Its phenomenon always appears in every Disney movie. They who are the antagonist one always fat and have bad face. It makes children think that the fat and ugly person is witch and cruel so it makes them have no place in the society. As the result, children who have the same physical appearance, that is fat and ugly, will just judge themselves as the witch one and feeling like they are not beautiful as girl and indirectly pessimist in making friends. In conclusion, the stereotype of beauty that comes to children's mind after watching Disney movie especially The Little Mermaid will make some children feeling inferior if they compare their selves with princess inside the movie.

While they who have the same physical appearance like Princess Ariel will consider their life as girl is perfect.

Interestingly, the tendency to pair attractiveness and intellectual competence in these movies is in contrast to existing literature showing that adults have only a moderate expectation that physically attractive individuals tend to be more intelligent than less attractive individuals (Eagly et al., 1991).

Women tend to believe that professional female models (who embody idealized attractiveness and thinness) are happier 
than are average females. Thus, the animated films of Disney seem to maintain and promote the belief that attractive people attain more overall positivity in their lives (Evans, 2003).

The quotation stated by Eagly and Evans clearly explained how in everyday life the portray of princess character in movie and the witch character influence in everyday life. Since the viewer is dominated by children, most children will have those kind of stereotype when defining beauty in life.

The second stereotype created by children after watching The Little Mermaid is the idea of life. Specifically the idea of life here is the future life that the girl wants. Princess Ariel is beautiful girl who has crush on Eric which depicts as the handsome one. Princess Ariel is wondering to meet Eric again, so she does everything include change herself becomes human. Eric has a crush on Princess Ariel because of her beautiful voice and physical appearance. "That voice. I can't get it out of my head. I've looked everywhere, Max - where could she be?" (00:43:42,460 --> 00:43:51,060). The quotation above said by Eric when he wonders to meet Princess Ariel again. Even he already meets Ariel, without her voice Eric doesn't want to accept even recognize Ariel.

As the result, the stereotype of future life is when the beautiful girl with beautiful voice marries the handsome boy. This stereotype is dangerous because it means that person only judges the other by the physical appearance and put the standard of couple on it. Not only the handsome one, but also rich. It is always become the ending of every Princess' love story in Disney movies. Even the girl comes from poor condition, but the girl meets the rich and handsome boy, they fall in love each other, and all the girl's problems are seem done.

Disney princess films illustrate distinct ideas of marriage and the ideal woman's future lifestyle. As indicated by many of the films, women should aspire to achieve a conventional type of life that results from falling in love with a supportive and wealthy male figure. (Bispo, 2012)

Above quotation explains that how Disney movie always depicted that kind of story. It also happens in The Little Mermaid, even Ariel has changed herself from mermaid into human, nothing she needs to worry about since she already reunited with Erric, her love. This scene, makes children think that the ideal husband is the handsome and rich man. Then, all problems of girls will fix after meet them.

One more thing that should aware from The Little Mermaid is how the idea of love here is most devoted to Eric rather than Triton. Princess Ariel falls in love with Eric and sacrifices everything she can for the sake of true love, Eric. She leaves his father, his family in the sea, and also dangered her Dad's life. "Daddy, I'm sorry! I - I - I didn't mean to. I didn't know - (Triton attacks the contract with a fierce blast from his trident, to no avail.)" (01:07:55,580 --> 01:07:58,980). The scene above when Ursula against Triton and Ariel, but Ariel chooses to escape from the war and simply meet Eric. This is the scene that should be awared, because children need a stereotype of giving more love to parent rather than another one else.

Disney movie influences most children because this is the "snack" of children in all era. They will just so obsessed after watching the movie. Children will easily take the character as their idol. What happens next is they tend to make their idol as their role model of everything in life. In fact, not all Disney's characters are justifiable in real life. Not all things describe in the movie are suitable to be applied in real life. The Little Mermaid has become the representative of all Disney movie by the story. It is harm for children because it influences their process in their character building.

Kohlberg (1969) and Turiel (7973) have shown that children go through phase of moral development. Younger children could therefore be expected to have a lower level of moral reasoning than older ones. If a child watches The Little Mermaid and thinks that beauty is when a girl has tall and slim body, completed by the good voice. It happens because children have a low moral reasoning than an adult. That phenomena will happen because the nature of children psychologically. 
Even if in fact cartoon is a fun media for children learning something but parents need to be aware of the possibility in negative content and morally wrong values. "Though cartoons are thought as entertaining, they have a positive as well as negative influence on children depending upon the theme and the content. Some cartoons are neutral and purely meant for entertainment, some are educational but some are violent to the core.” (Sudha, 2011).

\section{Conclusion}

In conclusion, as stereotype is a crucial issue for human, it is important to have a right stereotype since children. If there is a wrong concept of stereotype in the life of childhood it gives effect in the future life of the children. Because children's stereotype will long-lasting in mind.

\section{References}

Dovidio, J. F., Hewstone, M., Glick, P. \& Esses, M. (2008). Victoria. Prejudice, Stereotyping and Discrimination. Theoretical and Empirical Overview, 29-54.

Bazzini, D., Bazzini, L., Joslin, S., Regan, S., \& Martz, D. (2010). Do Animated Disney Characters Portray and Promote the Beauty-Goodness Stereotype. Journal of Applied Social Psychology, 40(10): 2687-2709.

Bispo, A. (2012). Fairytale Dreams: Disney Princesses' Effect on Young Girls' Self-Image. https://samanthahack.files.wordpress.com/2015/11/professor-letizia-schmid-disney-princess.pdf.

Sells, L. (1995). Where Do the Mermaids Stand? Voice and Body in the Little Mermaid, in E. Bell, L. Haas and L. Sells (eds.), From Mouse to Mermaid: The Politics of Film, Gender, and Culture, 175-192.

Kirkorian, H. L., Ellen, A. W., \& Daniel, R. A. (2008). Media and Young Children's Learning. The Future of Children, 39-61.

Bjorkqvist, K., \& Kristi, L. (1983). Children's Experience of Three Types of Cartoon at Two Age Levels. International Journal of Psychology, 77-93.

Sudha, A. G. (2011). Factors Influencing The Change in Behaviour of Children on Viewing Cartoon Programs-A Study. Namex International Journal of Management Research, 1 (1), 32-43.

Arsita, M., Adelina, H., \& Adha, M. M. (2013). Pengaruh Tayangan Film Kartun Terhadap Pola Tingkah Laku Anak Usia Sekolah Dasar. Jurnal Kultur Demokrasi, 1-13. 